\title{
An Unprecedented Ruthenium-Catalyzed Reductive Amination of Aldehydes with Tertiary Amines
}

\author{
Chan Sik Cho, $" *$ Ji Hỵk Park, Tae-Jeong Kim, and Sang Chul Shim" \\ ${ }^{\dagger}$ Research Institute of Industrial Technology, Kinthgpook National Lniversitw, Taegu 702-701, Korea \\ Department of Industrial Chemistry, College of Engineering, Kungpook National Lniversitw, Taegu 702-701, Korea \\ Recerved October 12, 2001
}

Keywords : Aldehỵde. Catalỵst. Ruthenium. Reductive amination. Tertiary amine.

The reductive amination of ketones and aldehydes with amines has been used as a tool for $N$-alkylation of amines. The process generally proceeds in two tandem steps. condensation between carbonyl compounds and amines to form an imine and reduction of the imine by a reducing agent. ${ }^{1,2}$ In sharp contrast to reductive amination of ketones and aldehydes with primary and secondary amines. little has known for that with teriary amines. During the course of our ongoing studies on homogeneous nuthenium catalysis. ${ }^{3.5}$ we recently developed an alkyl group transfer from alkylamines to $\mathrm{N}$-atom of anilines ${ }^{\hat{3}}$ as well as $\alpha$-carbon atom of ketones ${ }^{4}$ by an activation of $\mathrm{C}-\mathrm{N}$ bond of alkylamines. Prompted by these findings and intrigued by diverse reactivities of ruthenium catalysis, we have directed our attention to the reductive amination of aldehydes with tertiary amines, the process requiring the activation of $\mathrm{C}-\mathrm{N}$ bond of tertiary amines. Here we report an unprecedented ruthenium-catalyzed reductive anination of aldehydes with tertiary anines in an aqueous medium. ${ }^{6}$

Treatment of equimolar amounts of benzaldehyde (1a. 1: $\mathrm{R}=\mathrm{Ph}$ ) and tributylamine (2a. $\left.2: \mathrm{R}^{\circ}=\mathrm{Bul}\right)$ in an aqueous medium (dioxane- $\mathrm{H}_{2} \mathrm{O}$ ) at $180^{\circ} \mathrm{C}$ in the presence of a catalytic amount of $\mathrm{Ru}_{3}(\mathrm{CO})_{1:}(2 \mathrm{~mol} \%)$ under carbon monoxide pressure afforded benzyldibutylamine (3a) in $43 \%$ yield with conconitant formation of dibenzylbutylamine $(+\mathrm{a} .7 \%)$ (Table 1). ta seems to be formed by an amine scrambling process under the employed ruthenium catalyst. ${ }^{7}$ Performing the reaction in dioxane gave $3 \mathrm{a}$ in only $24 \%$ yield. Carbon monoxide was necessary for the effective formation of the reductive amination product. When the reaction was carried out under argon atmosphere, the yield of reductive amination product was lower than that under carbon monoxide. This result may suggest that carbon monoxide atmosphere hinders decarbonylation via a hydrido acyl rutheniun intermediate formed by oxidative addition of the carbon-hydrogen bond of the aldehyde to ruthenium. ${ }^{8}$ Lower reaction temperature resulted in lower yield of $3 \mathrm{a}\left(4 \%\right.$, at $150^{\circ} \mathrm{C}$ for $\mathrm{l} \mathrm{h} ; 35 \%$, at $180^{\circ} \mathrm{C}$ for $1 \mathrm{~h}$ ). Among the activity of various ruthenium precursors examined $\mathrm{Ru}_{3}(\mathrm{CO})_{12}$ revealed to be the catalyst of choice. Other ruthenium complexes such as $\mathrm{RuCl}_{3} n \mathrm{H}_{2} \mathrm{O}$ / $3 \mathrm{PPh}_{3} . \mathrm{RuCl}_{2}\left(\mathrm{PPh}_{3}\right)_{3}$, and $\mathrm{RuH}_{2}\left(\mathrm{PPh}_{3}\right)_{4}$ were nearly ineffective $\left(0-2 \%\right.$ yields of 3 a were formed at $180^{\circ} \mathrm{C}$ for $\left.\mathrm{i} h\right)$.

Having established reaction conditions. several aldelydes and tertiary amines were screened. As shown in Table 1, the
Table 1. Ruthenium-catalyzed reductive amination of aldehydes (1) with tertiary amines $(2)^{a}$

\begin{tabular}{|c|c|c|c|c|c|}
\hline $\begin{array}{c}\mathrm{RCHO} \\
1\end{array}$ & $\begin{array}{c}+\mathrm{NR}_{3} \\
2\end{array}$ & $\begin{array}{l}\frac{\mathrm{Ru}_{3}(\mathrm{CO})_{12}, \mathrm{CO}}{\text { dioxane }-\mathrm{H}_{2} \mathrm{O}} \\
180^{\circ} \mathrm{C}, 12 \mathrm{~h}\end{array}$ & $\stackrel{\mathrm{O}}{\underset{3}{\mathrm{RCH}_{2} \mathrm{NR}_{2}}}$ & $2+$ & \\
\hline \multirow{2}{*}{ Rurn } & \multirow{2}{*}{$\mathbf{1}(\mathrm{R}=$} & & \multirow{2}{*}{$2\left(\mathrm{R}^{\prime}=\right)$} & \multicolumn{2}{|c|}{ Isolated yield $(\%)$} \\
\hline & & ? & & 3 & 4 \\
\hline 1 & $\mathrm{Ph}$ & & $\mathrm{Bu}$ & 43 & 7 \\
\hline 2 & 4-MeC & ${ }_{2} \mathrm{H}_{4}$ & $\mathrm{Bu}$ & 41 & 7 \\
\hline 3 & $3-\mathrm{MeC}$ & $\mathrm{C}_{6} \mathrm{H}_{4}$ & $\mathrm{Bu}$ & 40 & 8 \\
\hline 4 & 2-MeC & ${ }_{6} \mathrm{H}_{4}$ & $\mathrm{Bu}$ & 40 & 4 \\
\hline 5 & 4-MeO & $\mathrm{DC}_{\mathrm{i}} \mathrm{H}_{4}$ & $\mathrm{Bu}$ & 41 & 6 \\
\hline 6 & 4-BrO & $\mathrm{C}_{6} \mathrm{H}_{4}$ & $\mathrm{Bu}$ & 44 & 2 \\
\hline 7 & 2-naph & hthyl & $\mathrm{Bu}$ & 54 & 6 \\
\hline 8 & 2-thiop & phenyl & $\mathrm{Bu}$ & 33 & 4 \\
\hline 9 & $\mathrm{Ph}$ & & isoanyl & 39 & 6 \\
\hline 10 & $\mathrm{Ph}$ & & heryl & 42 & 5 \\
\hline 11 & $\mathrm{Ph}$ & & octyl & 38 & 4 \\
\hline
\end{tabular}

${ }^{a}$ Reaction conditions: $1(1 \mathrm{mmol}) .2(1 \mathrm{mmal}) . \mathrm{Ru}_{3}(\mathrm{CO})_{12}(0.02 \mathrm{mmol})$. $\mathrm{CO}(10 \mathrm{~atm})$. dioxane $\mathrm{H}_{2} \mathrm{O}(5 \mathrm{~mL} 0.2 \mathrm{~mL}) .180^{\circ} \mathrm{C} .12 \mathrm{~h}$.

yield of $\mathbf{3}$ was not desicively affected by the position and electronic nature of the substituent on the aromatic ring of the aldehyde (runs 1-6). With polyaromatic and heteroaryl aldelydes, the corresponding reductive amination products were also formed in similar yields (runs 7 and 8). In the reaction between 1a and several trialkylamines. the corresponding reductive amination products 3 were also produced together with + (runs 9-11).

Typical experimental procedure is as follows. A mixture of $1 \mathrm{a}(\mathrm{l} \mathrm{mmol}) .2 \mathrm{a}(\mathrm{l} \mathrm{mmol}), \mathrm{Ru}_{3}(\mathrm{CO})_{12}(0.02 \mathrm{nmol})$. and dioxane $/ \mathrm{H}_{2} \mathrm{O}(5 \mathrm{~mL} / 0.2 \mathrm{~mL})$ was placed in a pressure vessel. After the system was flushed and then pressurized with carbon monoxide $(10 \mathrm{~atm})$. the misture was stirred at $180^{\circ} \mathrm{C}$ for $12 \mathrm{~h}$. The reaction mixture was poured into brine, extracted with $\mathrm{CHCl}_{3}$ and dried over $\mathrm{Na}_{2} \mathrm{SO}_{4}$. Removal of the solvent under reduced pressure left an oil. which was purified by column chromatography (ethyl acetate/hexane) to give $3 \mathbf{a}(43 \%)$ and $+\mathbf{a}(7 \%)$.

In summary, we have demonstrated that aldehydes can be reductively aminated with tertiary amines in an aqueous medium in the presence of a catalytic amount of a ruthenium catalyst under carbon monoxide pressure. The present reac- 
tion is a first example for reductive amination of aldehydes with tertiary amines. On the basis of others ${ }^{7 c}$ and our recent reports, ${ }^{3.4}$ the reaction mechanism is currently investigated.

Acknowledgment. The present work was supported by the Korea Research Foundation Grant (KRF-2001-015DP0296). C.S.C. gratefully acknowledges a MOE-KRF Research Professor Prograni (2001-050-D00015).

\section{References}

1. Dayagi. S. In The Chemistry of the Carbon-Nithogen Double Bond. Patai. S.. Ed.: Interscience: London. 1970: Chapter 2. pp $61-147$.

2. (a) In Contprehensive Organontetallic Chenistru: Trost. B. M.. Fleming. I.. Eds: Pergamon: Oxford. 1991. Vol. 8. (b) Hudlicky. M. Reactions in Organc Chemistry American Chemical Societ: Washington. D. C.. 1996

3. This transfer eventually leads to indoles and quinolines: Indoles: Cho. C. S.: Lim. H. K.: Shim. S. C.: Kim. T. J.: Choi. H.-J. Chent. Commin. 1998. 995: Cho. C. S.: Kim. J. H.: Shim. S. C. Tetrohedron Lett. 2000. 41. 1811: Cho. C. S.; Kinn. J. H. Kinn. T.-J.: Shim, S. C. Tetahedron 2001. 57, 3321; Cho, C. S.: Kim. T. K.: Yoon, S. W. Kim, T.-J: Shim, S. C. Bull. Korean them. Soc. 2001. 22. 545. Quinolines: Cho. C. S.: Oh. B. H.: Shim. S. C. Tetrohedron Lett 1999. 10. 1499: Cho. C. S.: Oh. B. H.: Shim. S. C. J. Heterocticlic Chem 1999. 36. 1175: Cho. C. S.: Oh. B. H: Shim. S. C: Oh, D. H. J. Heterocychic Chem. 2000. 37, 1315:
Cho, C. S.; Kim, J. S.; Oh, B. H.; Kim, T.J.: Shim. S. C.: Yoon. N. S. Tetrohedron 20(0). 56. 7747: Cho. C. S.: Oh. B. H.: Kim. J. S.: Kim. T.-I: Shim. S. C. Chent Contmum. 2000. 1885: Cho. C. S.: Kiml. T. K.: Kimn. T.-T.: Shim1. S. C.: Yoon. N. S. J. Heterocychic Chem in press

4. This transfer leads to regioselective $\alpha$-alkvaltion of ketones: Cho. C. S. Kim, B. T; Lee. M. J.: Kim. T.-J.: Shim. S. C. Angen: Chent. Int. Ed Engl. 2001. +0.958

5. Cho. C. S.: Kim. B. T.: Kim. T.-T.: Shim. S. C. J. Ong Chent 2001. 66. 9020

6. Aqueous-Phase Organometallic Catalysis, Cornils, B., Herrmann. W. A.. Eds.: Wiley-VCH: Weinheim. 1998

7. For transition metal-catalyzed amine exchange reaction, see: (a) Yoshimura. N.: Moritani. I.: Shimamura. T.: Murahashi. S.-I. J. Ant Chent. Soc. 1973. 95. 3038. (b) Murahashi. S.-I.: Hirano. T.: Yano. T. J. Am. Chent Soc. 1978. 100. 348. (c) Shvo. Y.: Laine. R. M. $J$ Chem Soc. Chem Commm 1980, 753. (d) Khai. B.-T Concilio, C.; Porzi, G. J. Organonet. Chem. 1981. 208, 249. (e) Khai. B.-T.: Concilio, C. Porzi. G. J. Org. Chem. 1981, f6. 1759 . (t) Arcelli. A.: Khai. B.-T.: Porzi. G. J. Orgunontet Chem. 1982. 231. C31. (g) Murahashi. S.-I.: Kondo. K.: Hakata. T. Tetrohedron Lett. 1982. 23. 229. (h) Laine. R. M.: Thomas. D. W.: Cary. L. W. J. Am. Chem. Soc, 1982, 104. 1763. (i) Jung, C. W: Fellmann. J. D: Garrou, P. E. Organometallics 1983. 2, 1042. (j) Murahashi. S.-I. Angew: Chem. Int Ed. Engl 1995. 34. 2413.

8. (a) Kondo. T.: Akazome. M.: Isuji. Y: Watanabe. Y. J. Org. Chent 1990. 55. 1286. (b) Colquhoun. H. M.: Thompson. D. T.: Twigg. M. V. Carbonlation: Direct Smbesis of Carbonl Conpounds: Plenum: New York. 1991: pp 205-255. 